\title{
ANALISIS KEBIJAKAN BATAS USIA PENSIUN PNS DALAM UU NO. 5 TAHUN 2014 TENTANG APARATUR SIPIL NEGARA
}

\author{
Argo Pambudi ${ }^{1}$ \\ Joko Kumoro ${ }^{2}$ \\ ${ }^{1)}$ Fakultas Ilmu Sosial, Universitas Negeri Yogyakarta \\ e-mail: argo_pambudi@uny.ac.id \\ ${ }^{2)}$ Fakultas Ekonomi, Universitas Negeri Yogyakarta \\ e-mail: jokokum@uny.ac.id
}

\begin{abstract}
This research is motivated by a deep desire of understanding the changes of policy content of the Limit of Retirement Age of civil servants in the Government of the city of Yogyakarta. Substantive analysis of this research focused on the acceptability of the regulation of the Limit Age of Retirement. The purpose of this study is to contribute to the empowerment of the state apparatus through a intensification of existing civil servants, preventing civil servants who are still productive to leave the bureaucratic structure in earlier - which means a waste of state finances - and to propose alternative arrangements of future policy of retirement age for civil servants. The research method used in this study is a Mixed Methods Analysis, which is a combination of both Survey Method with Qualitative Descriptive research methods. Informants and respondents of this study is the structural and functional officials in the city government that is actually involved in the problems associated with the implementation of this regulatory changes. The results of this research showed that most civil servants who was observed received this new rules, but from the perspective of the municipal government organization this policy raises a number of internal problems, especially problems related to fulfilment structural positions pertaining with limited in number of the existing number of civil servants.
\end{abstract}

Keywords : retirement age, civil servants productivity, policy content

\section{PENDAHULUAN}

Ketentuan usia pensiun sangat penting dalam perjalanan karier setiap PNS di jajaran birokrasi. Dibandingkan tahap-tahap sebelumnya, seperti rekrutmen, penempatan, mutasi/ promosi jabatan, dan lain sebagainya, tahap memasuki masa pensiun ini memiliki makna tersendiri. Dari sudut pandang pribadi PNS yang bersangkutan, usia menjelang pensiun merupakan "puncak karier". Sementara itu dari sudut pandang kepentingan negara, pada saat menjelang pensiun tersebut efektivitas pembinaan PNS dan sumber daya yang telah dikeluarkan untuk membiayainya juga sedang berada pada "posisi puncak". Artinya, pada saat-saat itu pengalaman, wawasan, kematangan mental, serta banyak aspek lain hasil pembinaan PNS yang bersangkutan sedang mencapai puncak efektivitasnya. Hal ini tentu sangat dibutuhkan negara. Sementara itu pada saat yang sama garis finish batas usia pensiun sudah tampak di depan mata. Dalam banyak kasus finish pada usia tertentu itu belum tentu dikehendaki, dan bukan merupakan tujuan utama PNS yang bersangkutan pada saat itu. Kondisi ini kiranya tidak terlalu baik sebagai pemacu prestasi PNS di akhir masa pengabdiannya. Pada kondisi seperti ini sudah 
pasti konsentrasi PNS yang bersangkutan terpecah dan kontra-produktif. Fenomena tersebut sebenarnya bisa dimaknai sebagai penyalah-gunaan (abuse) atau inefficiency pemanfaatan SDM di jajaran birokrasi, karena puncak pengalaman, puncak kematangan jiwa, serta puncak keluasan wawasan PNS menjelang purna tugas itu tidak dimanfaatkan secara maksimal untuk negara.

Usia pensiun yang terlampau muda - sering tidak dikehendaki PNS yang bersangkutan - bisa berakibat kontra-produktif bagi pelaksanaan tugas dan fungsi birokrasi pada umumnya. Banyak kasus menunjukkan bahwa PNS yang memasuki usia pensiun dari berbagai aspek masih memenuhi syarat untuk bisa bekerja dengan baik. Hanya karena peraturan pemerintah sajalah yang memaksa mereka tidak melanjutkan pengabdiannya.

Pada Januari 2014 telah disahkan UU Nomor 5 Tahun 2014 tentang Aparatur Sipil Negara (ASN). UU itu antara lain mengatur Batas Usia Pensiun (BUP) Pegawai Negeri Sipil (PNS). Satu diantaranya yang paling urgent adalah ketentuan Pasal 90 huruf a yang menentukan bahwa "PNS diberhentikan dengan hormat karena mencapai batas usia pensiun, yaitu 58 tahun bagi Pejabat Administrasi". Disebut yang paling urgent karena pasal itu merupakan ketentuan yang paling tinggi - dalam keadaan tanpa sebab khusus. Sebab khusus yang dimaksud adalah meninggal dunia, atas permintaan sendiri, perampingan organisasi dan/atau dinilai tidak cakap jasmani dan/atau rohani sehingga tidak dapat menjalankan tugas dan kewajibannya. Penelitian ini bermaksud ingin mengetahui secara mendalam bagaimana akseptabilitas substantif peraturan $B U P$ itu di lokasi penelitian untuk tujuan mencari berbagai bentuk persoalan implementasinya, serta mencari solusi komprehensifnya.

Peraturan BUP pasal 90 UU itu menentukan 2 pengecualian yaitu BUP untuk Pejabat Pimpinan Tinggi (60 tahun) dan BUP untuk pejabat fungsional (ditentukan dengan peraturan per-UU-an lain yang berlaku). Oleh karena itu di tingkat implementasi terdapat banyak variasi. Akibat adanya variasi tersebut maka dimungkinkan munculnya ketidak-harmonisan suasana hati yang dikalangan PNS, yaitu manakala mereka membandingkan dan menilainya sebagai bentuk diskriminasi oleh si pembuat kebijakan tersebut. Suasana yang tidak harmonis ini lebih sering bersifat latent daripada terbuka, karena doktrin birokrasi pada umumnya mengharuskan PNS senantiasa patuh dan taat pada peraturan per-UU-an yang berlaku. Namun demikian secara substansial dampaknya sudah pasti, yaitu mempengaruhi perilaku produktif PNS yang bersangkutan, baik secara langsung ataupun tidak langsung. Berdasarkan latar belakang inilah maka ide penelitian ini dikembangkan.

Penelitian ini bertujuan: (1) Memahami secara lengkap dan mendalam karakteristik akseptabilitas substantif Peraturan BUP itu di kalangan PNS di lokasi penelitian; (2) Mengantisipasi berubahnya potensi masalah menjadi masalah nyata, khususnya yang terkait dengan penurunan produktivitas kerja birokrasi pemerintah akibat implementasi peraturan BUP ini; (3) Menyusun bahan asistensi untuk pemerintah dalam menentukan strategi penerapan peraturan BUP tersebut di lapangan. Kesemuanya itu ditujukan agar bisa dicapai peningkatan produktivitas peraturan BUP tersebut.

Prediksi berubahnya potensi masalah menjadi masalah nyata menyulut interpretasi prediktif bahwa peraturan BUP yang tingkat akseptabilitasnya rendah tidak akan mampu memberdayakan SDM birokrasi secara optimal. Peraturan ini tidak akan berdampak positif pada peningkatan efektivitas, efisiensi serta peningkatan produktivitas kerja organisasi pemerintahan di kemudian hari. Dalam batas-batas tertentu pemberlakukan peraturan BUP yang dipaksakan justru kontra-produktif atau menjadi penghambat pelaksanaan fungsi-fungsi birokrasi yang 
ideal. Dengan penelitian ini kekawatiran tersebut bisa diantisipasi dan dicegah kehadirannya. Inilah urgensi penelitian ini.

\section{METODE PENELITIAN}

Penelitian ini dilaksanakan dengan menggunakan mix methods analysis, yaitu perpaduan antara metode penelitian analisis deskriptif kualitatif dan metode survai (kuantitatif). Pengumpulan data kualitatif dilakukan dengan menggunakan teknik wawancara terhadap para pejabat struktural dan fungsional di lingkungan Pemerintah Kota Yogyakarta yang benarbenar mengalami masalah terkait dengan implementasi peraturan batas usia pensiun ini. Di samping itu metode wawancara juga digunakan sebagai sarana cross check dengan data lain yang validitasnya perlu diperkuat lagi.

Populasi penelitian ini adalah seluruh PNS non-guru di lingkungan organisasi pemerintah Kota Yogyakarta tahun 2014, sebesar 4.184 orang. Pengambilan sampel ditentukan secara Propotionate Stratified Random Sampling. Cara ini dilakukan dengan pertimbangan kondisi satuan elementer tersebar di banyak unit organisasi dengan lokasi geografis yang tidak beraturan. Ada yang berada di Balai Kota sebagai kantor pusat dan ada pula yang berada di kantor dinas, di kantor kecamatan, kelurahan dan sebagainya. Pengambilan sampel di kantor pusat saja, atau di kantor kecamatan saja kurang representatif. Maka dari itu pengambilan sampel dengan cara Propotionate Stratified Random Sampling adalah yang paling tepat. Mengenai keseluruhan jumlah satuan elementer sampel ditentukan minimal 160 responden. Perinciannya dari Balai Kota 20 responden dan dari masing-masing kecamatan 10. Kota Yogyakarta memiliki 14 kantor kecamatan, yaitu: Danurejan, Gedongtengen, Gondokusuman, Gondomanan, Jetis, Kotagede, Kraton, Mantrijeron, Mergangsan, Ngampilan, Pakualaman, Tegalrejo, Umbulharjo dan Wirobrajan. Jumlah keseluruhan responden minimal 160 itu dipandang telah representatif.

Pengumpulan data penelitian ini dilakukan dengan menyebar daftar pertanyaan kepada responden sampel. Selanjutnya, untuk data yang tidak mungkin dikumpulkan melalui daftar pertanyaan pengumpulannya dilakukan dengan teknik wawancara secara langsung dengan informan penelitian, serta telaah dokumen-dokumen yang tersedia. Ketiga-tiganya dipadukan sebagai sarana crosscheck validitas data terkumpul. Teknik wawancara digunakan untuk mengumpulkan data kualitatif, yang berupa deskripsi tentang berbagai bentuk persoalan terkait dengan BUP ini. Informan yang dijadikan nara sumber adalah Kepala Badan Kepegawaian Daerah Pemerintah Kota Yogyakarta dan beberapa personalia PNS yang terlibat langsung terkait dengan pelaksanaan peraturan baru tentang BUP ini.

\section{HASIL DAN PEMBAHASAN}

Hasil penelitian ini dibedakan ke dalam 2 kelompok, yaitu temuan yang terkait dengan konten normatif BUP dalam UU No. 5 tahun 2014 dan akseptabilitas substantif di tingkat lapangan.

\section{A. Norma BUP dalam UU No. 5 Tahun 2014}

1. Konsep yang Terlampau Operasional : Menutup ruang diskresi pemecahan masalah Regulasi BUP yang dituangkan dalam UU No. 5 Tahun 2014 merupakan kebijakan publik level negara. Proses penyusunan hingga ratifikasinya tidak hanya melibatkan lembaga executive (pemerintah) saja, tetapi juga melibatkan DPR sebagai lembaga legislative yang mewakili seluruh rakyat Indonesia. Kebijakan level negara ini direncanakan mengikat semua WN di 
semua daerah dan di semua sektor di seluruh wilayah hukum Republik Indonesia. Oleh karena itu menuntut sifat yang general, mayor, konseptual dan strategis di tingkat nasional. Dengan kata lain kebijakan ini lebih banyak menuntut format regulasi dan definisi konsep dengan tingkatan abstraksi yang tinggi dan berfungsi strategis di tingkat nasional, daripada format teknis operasional yang spesifik. Fakta temuan penelitian ini menunjukkan bahwa rumusan regulasi BUP dalam UU Nomor 5 Tahun 2014 ini terlampau operasional dan terlampau teknis. Pasal 90 UU itu mengatur BUP dengan cara sangat teknis - sampai dengan menyebut angka BUP secara definitif, yaitu : 58 (lima puluh delapan) tahun bagi Pejabat Administrasi, 60 (enam puluh) tahun bagi Pejabat Pimpinan Tinggi dan sesuai dengan ketentuan peraturan per-UUan bagi Pejabat Fungsional. Format pengaturan yang definitif bagi Pejabat Administrasi dan Pejabat Pimpinan Tinggi dalam UU ini kurang tepat, karena menutup peluang diskresi untuk penyelesaian persoalan khusus atau unik dan persoalan-persoalan lain yang unpredictable yang membutuhkan ketentuan di luar batas definisi konsep ketentuan tersebut. Oleh karena itu pasal ini berpotensi memunculkan masalah implementasi di lapangan dan mendorong munculnya pelanggaran terhadap substansi pasal 90 itu sendiri.

Dibandingkan dengan UU No. 8 Tahun 1974, norma BUP dalam UU No. 5 Tahun 2014 menggunakan batasan yang lebih ketat dan lebih operasional. Batasan yang lebih ketat dan operasional inimembuatketentuan itu bisa langsung dilaksanakan tanpa harus menungguterbitnya peraturan pelaksananya. Dengan kata lain format aturan BUP dalam UU itu memberikan ruang gerak yang lebih terbatas bagi para pelaksananya ketika mereka harus membuat keputusan yang "berbeda" dengan definisi ketat aturan UU itu. . Tidak ada lagi variasi aturan pelaksanaan yang bisa ditemui. Tidak ada lagi "tawar-menawar" dan kompromi di tahap implementasi - walau mungkin ada pertimbangan lain yang lebih urgent. Di satu sisi ketentuan hukum yang ketat ini lebih baik karena menciptakan kepastian hukum yang seragam dan mudah dilaksanakan, namun di sisi lainnya sistem regulasi menjadi tidak flexible. Mandul ketika menghadapi kasus unik atau khas, di luar prediksi para pembuat kebijakan publik itu. Fakta empiris persoalan yang berkembang di lapangan itu bisa tidak seragam, bisa memiliki ke-khas-an tersendiri. Menghadapi keanekaragaman persoalan lapangan yang seperti ini, pola pengaturan yang detail akan tidak berdaya dan bahkan kontra-produktif, dan bisa jadi memunculkan masalah baru. Pola pengaturan yang detail dalam UU itu tidak memberikan keleluasaan bagi pejabat pelaksananya di lapangan untuk mengambil keputusan khusus (discretion) bilamana harus mengatasi persoalan publik yang urgent dan membutuhkan penanganan khusus pula. Rumusan definitif ketat tentang BUP bisa ditemukan dalam Pasal 87 ayat (1) UU No. 5 Tahun 2014 dibandingkan dengan Pasal 23 ayat (1) UU No. 8 Tahun 1974 sebagai berikut:

Pasal 87 - UU No. 5 Tahun 2014:

(1) PNS diberhentikan dengan hormat karena:

a. meninggal dunia;

b. atas permintaan sendiri;

c. mencapai batas usia pensiun;

d. perampingan organisasi atau kebijakan pemerintah yang mengakibatkan pensiun dini; atau

e. tidak cakap jasmani dan/atau rohani sehingga tidak dapat menjalankan tugas dan kewajiban. 
Pasal 23 - UU No. 8 Tahun 1974:

(1) Pegawai Negeri Sipil dapat diberhentikan dengan hormat, karena:

a. permintaan sendiri;

b. telah mencapai usia pensiun;

c. adanya penyederhanaan organisasi Pemerintah;

d. tidak cakap jasmani atau rohani sehingga tidak dapat menjalankankewajiban sebagai Pegawai Negerl Sipil.

Perhatikan tidak digunakannya kata "dapat" dalam pasal 87 UU No. 5 Tahun 2014 tersebut. Bandingkan hal yang sama dengan pasal 23 UU No. 8 Tahun 1974 tersebut. Dalam pasal 23 UU No. 8 Tahun 1974 itu didapati ketentuan yang sifatnya pilihan (option). Penggunaan kata "dapat" menunjukkan bahwa UU No. 8 Tahun 1974 itu masih memberikan alternatif keputusan lain yang dianggap perlu, yaitu bilamana ada pertimbangan yang lebih urgent pada tahap implementasinya.

\section{Mencapai BU sebagai Alasan Pemberhentian PNS: Tidak berdampak langsung pada} peningkatan efektivitas pelaksanaan tugas

Pasal 87 ayat (1) UU ASN menyatakan bahwa PNS diberhentikan dengan hormat karena 5 alasan, yaitu: (a) meninggal dunia; (b) atas permintaan sendiri; (c) mencapai batas usia pensiun; (d) perampingan organisasi atau kebijakan pemerintah yang mengakibatkan pensiun dini; (e) tidak cakap jasmani dan/atau rohani sehingga tidak dapat menjalankan tugas dan kewajiban. Di antara alasan-alasan pemberhentian dengan hormat tersebut, alasan mencapai batas usia pensiun adalah satu-satunya alasan yang tidak terkait secara langsung dengan efektivitas pelaksanaan tugas pekerjaan PNS yang bersangkutan. Selanjutnya pada Pasal 90 batas usia pensiun (BUP) sebagaimana dimaksud dalam Pasal 87 ayat (1) huruf c itu ditentukan secara definitif 58 (lima puluh delapan) tahun bagi Pejabat Administrasi, 60 (enam puluh) tahun bagi Pejabat Pimpinan dan sesuai dengan ketentuan peraturan perundang-undangan bagi Pejabat Fungsional. Dengan aturan definitif itu maka tertutup kemungkinan pemberlakuan BUP di luar ketentuan umur tersebut kecuali ditentukan lain dengan peraturan yang setingkat atau yang lebih tinggi. Minimal harus menggunakan PERPU atau UU yang lain. Selanjutnya, PNS yang tidak menduduki jabatan tertentu sebagai Pejabat Administrasi, Pejabat Pimpinan dan Pejabat Fungsional tidak diatur dalam UU ASN ini.

Aturan BUP itu tidak terkait secara langsung dengan efektivitas pelaksanaan tugas PNS karena faktor kemampuan SDM PNS dan efektivitas pelaksanaan tugas PNS itu tidak selalu berkorelasi langsung dengan faktor usia, namun lebih banyak ditentukan oleh faktor lain, seperti faktor kesehatan, faktor motivasi dan semangat kerja, dan lain sebagainya. Jadi bisa saja seorang PNS itu sudah mencapai BUP namun masih produktif, sebaliknya ada pula seorang PNS berusia relatif muda, masih jauh dari BUP namun sakit-sakitan sehingga tidak mampu lagi bekerja dengan baik. Oleh karena itu, dihadapkan pada persoalan seperti ini UU No. 5 Tahun 2014 itu akan menghadapi masalah implementasi. Ujung-ujungnya pelaksanaan peraturan BUP secara konsisten tidak berdampak pada peningkatan efektivitas dan efisiensi pelaksanaan substansi tugas-tugas pemerintahan dan pembangunan. Namun hanya sekedar melaksanakan peraturan yang bersifat prosedural saja. Oleh karena itu peningkatan kinerja organisasi pemerintahan (birokrasi) tidak bisa diharapkan dari pelaksanaan ketentuan BUP ini.

Selanjutnya, pelaksanaan regulasi BUP semacam ini bisa pula dikategorikan bertentangan dengan kaidah profesionalisme PNS. Usia produktif setiap orang itu berbeda-beda, tergantung faktor kesehatan - baik kesehatan fisik maupun mental - dan kesanggupan/komitmen PNS yang 
bersangkutan untuk bekerja. Jadi dengan asumsi ini tidak ada alasan kuat menetapkan masa pensiun berdasarkan faktor usia sebagai standar tunggal. Seharusnya perlu dipertimbangkan pula faktor kemampuan melaksanakan tugas pekerjaan secara simultan. Apa urgensi ditetapkannya batas usia pensiun itu secara definitif ? pertanyaan ini tidak bisa dijawab dari sisi peningkatan efektivitas organisasi. Persoalan yang disasar oleh perubahan BUP UU ini tidak jelas.

\section{Regulasi BUP dalam Format UU Kurang Responsif terhadap Dinamika Persoalan}

Regulasi BUP bagi PNS dalam UU No. 5 Tahun 2014 ini tergolong sedikit. Substansinya hanya termuat dalam 3 pasal saja, yaitu pasal 87, 90 dan 91. Bila dibandingkan dengan UU yang digantikannya, yaitu UU No. 8 Tahun 1974 tentang Pokok-pokok Kepegawaian - dan perubahannya - porsi tersebut sudah jauh lebih besar. Namun, besarnya porsi tersebut tidak menunjukkan perluasan substansi yang diaturnya, namun "hanya" berisi penjabaran ketentuan BUP menjadi lebih detail. Singkatnya, pasal 90 dan 91 itu hanya merupakan pelengkap untuk pelaksanaan pasal 87 saja.

Selanjutnya, dipadu dengan tingkat abstraksi definisi konsep yang digunakannya (sangat operasional) maka perpaduan ini berkonsekuensi memunculkan potensi masalah di tingkat implementasi. Bandingkan dengan norma BUP dalam UU No. 8 Tahun 1974. Pada pasal 23 UU No. 8 Tahun 1974 itu jelas terlihat bahwa BUP tersebut tidak diatur secara rinci. Pada pasal-pasal lain dan penjelasannya juga tidak ditemukan perinciannya. Satu-satunya pasal dalam UU itu yang relevan dan merupakan kelanjutan dari norma BUP pasal 23 tersebut adalah pasal 36. Secara lengkap berbunyi : "Perincian tentang hal-hal yang dimaksud dalam Pasal 5 sampai dengan Pasal 35 Undang-undang ini diatur lebih lanjut dengan peraturan perundangundangan". Singkatnya, format regulasi BUP yang terkandung dalam UU No. 8 Tahun 1974 itu memiliki tingkat abstraksi yang tinggi. Pola pengaturan BUP seperti ini memiliki keunggulan inherent di dalamnya, yaitu tidak mudah usang atau ketinggalan jaman karena lebih mampu menyesuaikan diri dengan dinamika, perubahan bentuk dan struktur permasalahan yang disasar melalui fleksibilitas peraturan pelaksanaannya (Peraturan Pemerintah, Keputusan Presiden atau peraturan pelaksanaan yang lainnya). Peraturan pelaksana UU itu dibuat belakangan, dan sekaligus bisa berfungsi sebagai instrumen untuk merespon munculnya variasi masalah yang unpredictable di lapangan tanpa melanggar pasal, semangat dan tujuan UU itu. Disamping itu, peraturan pelaksana UU itu juga bisa dijadikan instrumen untuk memenuhi kelengkapan pemecahan masalah sesuai kebutuhan yang merupakan bagian integral dari dinamika, bentuk dan pola unpredictable problem pada saat penyusunan UU tersebut.

\section{Regulasi BUP dalam Bentuk UU: Sulit dilakukan amandemen}

Sebagaimana telah dikemukakan di atas, bahwa UU itu adalah salah satu bentuk kebijakan publik level negara, dimana proses penyusunan hingga ratifikasinya tidak hanya melibatkan lembaga executive saja, tetapi juga melibatkan DPR sebagai lembaga legislative. Ditinjau dari aspek proses penyusunannya, penyusunan UU jauh lebih rumit dibandingkan dengan proses penyusunan kebijakan bentuk lainnya. Hal demikian berlaku juga untuk proses penyusunan berbagai bentuk amandemen, seperti revisi, terminasi ataupun restrukturisasi UU. Sebaliknya, penyusunan peraturan pelaksana UU, seperti Peraturan Pemerintah (PP), Keputusan Presiden (Kepres) dan/atau peraturan pelaksana lainnya jauh lebih sederhana, karena hanya perlu melibatkan unsur kekuasaan eksekutif saja. Jadi dikaitkan dengan temuan penelitian ini, substansi peraturan BUP yang telah dirumuskan secara terperinci dalam UU No. 5 Tahun 2014 itu - bilamana membutuhkan perubahan - maka proses perubahannya akan jauh lebih sulit 
dilakukan dan membutuhkan waktu dan tenaga lebih besar karena harus melibatkan unsur eksekutif dan legislatif (DPR) secara bersamaan. Selanjutnya, terdapat pula kemungkinan hambatan lain, berupa kemungkinan "benturan" kepentingan yang lebih besar antara unsur birokrasi (pemerintah) dan non-birokrasi - terutama DPR. Pengalaman selama empat puluh tahun (1974 - 2014) telah membuktikannya. Implementasi peraturan BUP dalam UU No. 8 Tahun 1974 itu tidak banyak menemui persoalan yang berarti. Norma BUP yang sangat umum dalam UU No. 8 Tahun 1974 justru sangat menguntungkan. Walau peraturan BUP dalam UU itu dilaksanakan melalui Peraturan Pemerintah (PP), Peraturan Presiden (Perpres), Keputusan Presiden (Kepres) dan Peraturan Menteri (Permen), maksud, tujuan serta semangat regulatif dalam UU No. 8 Tahun 1974 itu tetap terjaga.

\section{Norma Regulasi BUP Tidak Terkoordinasi, Tidak Terintegrasi dan Overlap}

Paling tidak, terlihat 3 pola permasalahan yang perlu dicatat terkait dengan aturan BUP PNS sebelum lahirnya UU No. 5 Tahun 2014 itu, yaitu : (a) Penyusunannya yang tidak terintegrasi, (b) Terdapat overlap pengaturan BUP di tingkat UU, dan (c) Pengaturan BUP kebanyakan bersifat ad hoc yang dipermanenkan - hasil perpanjangan aturan utama. Sementara itu UU No. 5 Tahun 2014 tidak khusus ditujukan untuk mengatasi persoalan tersebut.

Selain diatur dalam UU Nomor 5 Tahun 2014 masih ada beberapa UU lain yang juga mengatur BUP ini. Artinya, secara langsung ataupun tidak langsung BUP PNS di Indonesia selama ini diatur dengan peraturan ganda (overlap). Sebelum lahirnya UU No. 5 Tahun 2014 BUP PNS - dalam UU itu PNS dikategorikan sebagai bagian dari Aparatur Sipil Negara - telah diatur dalam beberapa UU, namun masing-masing tidak saling berhubungan. Ketika dicermati secara lebih dalam diktum "menimbang" dan "memperhatikan" semua UU yang mengatur obyek BUP PNS itu ternyata semuanya tidak memasukkan unsur keterkaitan atau kebersamaan mengatur (juncto). Hal ini menunjukkan bahwa proses penyusunan regulasi/peraturan BUP PNS tersebut selama ini tidak terkoordinasi sehingga tidak membentuk satu kesatuan sistem regulasi yang terintegrasi. Substansinya overlap satu sama lain. Selanjutnya menjadi tidak jelas terlihat dimana posisi UU ASN ini dalam sistem regulasi BUP di Indonesia. Apakah UU ASN ini menjadi UU pokok (lex generalis) yang berfungsi memayungi UU yang lain, ataukah UU ASN ini hanya sekedar aturan pelengkap saja.

UU Nomor 8 Tahun 1974 tentang Pokok-Pokok Kepegawaian - sebagaimana telah diubah dengan UU Nomor 43 Tahun 1999 - UU No. 16/2004 tentang Kejaksaan Republik Indonesia, UU No. 3/2006 tentang Peradilan Agama, UU No. 14 Tahun 2005 tentang Guru dan Dosen, UU No. 12 Tahun 2012 tentang Pendidikan Tinggi merupakan contoh produk proses legislasi yang tidak terpadu. Legislasi ke-5 UU tersebut seolah-olah berjalan sendiri-sendiri untuk mencapai tujuan sektoralnya masing-masing, tanpa memperhatikan kepentingan sektor lainnya. Sebagai bukti:

1) Pada diktum menimbang dan mengingat dalam UU No. 14 Tahun 2005 tentang Guru dan Dosen hanya dimasukkan materi mengingat UUD 1945 dan UU No. 20 Tahun 2003 tentang Sistem Pendidikan Nasional. Tidak mencantumkan materi mengingat UU tentang Pokok-pokok Kepegawaian - apalagi mengingat peraturan pelaksanaannya. Padahal ke dua UU itu mengatur obyek yang sama.

2) Sama halnya dengan UU Nomor 12 Tahun 2012 tentang Pendidikan Tinggi. UU ini lebih parah lagi, karena hanya mencantumkan materi pertimbangan pasal 20, 21 dan 31 UUD 1945 saja. Hal ini sama artinya dengan mengabaikan UU atau peraturan lain yang setingkat, padahal keduanya sama-sama mengatur BUP PNS sebagai obyek regulasi. 
3) UU No. 3/2006 tentang Perubahan Atas UU No. 7 Tahun 1989 tentang Peradilan Agama juga sama, tidak menunjukkan keterpaduan dengan UU tentang pokok-pokok kepegawaian. Padahal keduanya mengatur obyek regulasi yang sama (BUP PNS). Legislator atau perancang/pembuat UU ketika menyusun UU No. 3 Tahun 2006 itu, secara etika seharusnya memasukkan UU lain yang pengatur obyek yang sama dalam diktum "menimbang" atau "mengingat". Sehingga dalam pembuatan peraturan pelaksanaan ke 2 UU tersebut (UU no. 3/2006 dengan UU No. 8 Tahun 1974) nantinya tidak memunculkan disharmoni, baik yang bersifat overlap maupun antagonist. Pasal 18 UU No. 3 tahun 2006 mengatur BUP Ketua dan Wakil Ketua - dan juga hakim Pengadilan Agama dan Pengadilan Tinggi Agama (Aparatur Negara). Namun tidak memasukkan UU tentang Pokok-pokok Kepegawaian sebagai bahan yang harus diingat. Padahal banyak UU lain dimasukkan dalam diktum "menimbang" ini, yaitu: UU No. 14 Tahun 1985 tentang Mahkamah Agung sebagaimana telah diubah dengan UU Nomor 5 Tahun 2004 tentang Perubahan atas UU No. 14 Tahun 1985 tentang Mahkamah Agung, UU Nomor 7 Tahun 1989 tentang Peradilan Agama, UU Nomor 4 Tahun 2004 tentang Kekuasaan Kehakiman.

Biasanya persoalan ketidakterpaduan penyusunan UU yang menyangkut pemberhentian ASN ini tidak dianggap sebagai persoalan ketika tidak ada pihak yang dirugikan atau pihak yang mempersoalkan. Namun bilamana pada suatu saat ada pihak yang merasa dirugikan, mempersoalkan dan menuntut secara hukum, misalnya mengajukan judisial review ke Mahkamah Agung atau Mahkamah Konstitusi - dan menang/dikabulkan - maka hal ini baru disadari menjadi persoalan yang berimplikasi luas. Masih bisa diingat kasus pemberhentian dan pengangkatan Jaksa Agung Hendarman Supanji tanpa Surat Keputusan Presiden (Keppres) pada kabinet Indonesia Bersatu jilid I dan II pada tahun 2009. Hal itu baru menjadi persoalan ketika dituntut oleh Mantan Menteri Hukum dan HAM Yusril Izha Mahendra ke MK dan kemudian dikabulkan. Kalau dulu kasus ini tidak segera "ditutup secara politis" dan tidak direspon masyarakat dengan sikap yang apologize maka persoalan yang ditimbulkannya menjadi sangat luas dan berpenetrasi ke semua aspek kehidupan masyarakat. Keabsahan semua keputusan yang pernah dibuat oleh Jaksa Agung tanpa Keppres tersebut - berikut semua aktivitas pelaksanaannya - menjadi tidak sah pula (illegal).

Penyusunan kebijakan publik level UU yang tidak terintegrasi mengisyaratkan kepentingakepentingan publik yang diperjuangkan melalui UU itu dipersepsikan bersifat independen dan tidak terkait satu sama lainnya oleh para legislatornya. Padahal di dalam persepsi itu selalu terkandung asumsi yang mengkonstruksinya. Sementara itu keberadaan asumsi dalam persepsi itu tidak selalu benar dalam kenyataan empiris. Kalaupun benar, kebenarannya tidak selalu permanen. Bisa sangat dinamis, bisa berubah dari waktu ke waktu. Dengan kata lain dalam kenyataan empiris independensi absolut kepentingan publik sektor yang satu dengan sektor yang lain itu tidak pernah ada di lapangan. Hanya soal waktu saja yang menjawabnya, kapan dependensi antar sektor itu terungkap. Lazimnya ketika dipendensi itu tidak diakomodasi dalam UU, maka ketika terungkap, sudah berubah bentuk menjadi masalah pelanggaran hukum yang nyata di masyarakat. 


\section{B. Akseptabilitas Peraturan BUP PNS Berdasarkan UU No. 5 Tahun 2014}

1. Preferensi PNS tentang Batas Usia Pensiun

Sebagian terbesar responden (51\%) memilih 58 tahun sebagai norma BUP terbaik (ideal) menurut versi mereka (Gambar 1). Hal ini bermakna bahwa akseptabilitas substantif ketentuan BUP dalam UU No. 5 Tahun 2014 itu tinggi. Namun tidak tinggi sekali (extreme). Disamping karena tidak ada nuasa penolakan yang menyolok, jawaban sebesar $49 \%$ sisanya tidak bersifat oposisi terhadap ketentuan BUP itu, namun lebih bersifat menambahi (complementary). Kesemuanya tersebar ke dalam 3 kategori yang mengandung makna sendiri-sendiri, sebagai berikut:

a. Pilihan BUP yang lebih rendah dari 58 tahun - sebagaimana ditentukan dalam UU ASN - ada $24 \%$, terdiri dari pilihan 56 tahun ada $16 \%$ dan kurang dari 56 tahun ada $8 \%$.

b. Pilihan BUP yang lebih tinggi daripada ketentuan 58 tahun sebagaimana dalam UU ASN ada $19 \%$. Terdiri dari pilihan 60 tahun ada $18 \%$ dan pilihan 62 tahun $1 \%$. Sementara itu tidak ada responden yang memilih BUP lebih dari 62 tahun - opsi lain yang ditawarkan adalah 64 tahun, 66 tahun, 68 tahun dan seterusnya.

c. Yang sangat menarik adalah terdapatnya fakta yang menunjukkan ada $6 \%$ responden memilih opsi BUP tidak perlu diatur secara ketat. Dari $6 \%$ responden itu kebanyakan mereka memberi argumentasi senada, yaitu : Sebaiknya BUP ditentukan pemerintah secara longgar, agar bisa diperpanjang sesuai kebutuhan instansi dan keputusan pensiun itu diserahkan kepada PNS yang bersangkutan.

Interpretasi lebih lanjut menunjukkan bahwa pilihan BUP yang berbeda dari yang sudah ditentukan dalam UU ASN kebanyakan masih berada di sekitar 58 tahun itu juga, yaitu 56 tahun (16\%) dan 60 tahun (18\%). Pilihan selain itu (kurang dari 56 tahun dan lebih dari 62 tahun) terlalu kecil untuk layak ditindak-lanjuti. Jadi perbedaan keinginan responden dengan aturan kebijakan yang sudah diambil tidak terlampau besar. Fenomena ini mengisyaratkan adanya keinginan diberlakukannya fleksibilitas terbatas peraturan BUP di dalam range 56-60 tahun yang disesuaikan dengan kebutuhan instansi dan preferensi individu PNS yang bersangkutan.

Pilihan responden cenderung ke arah BUP lebih tinggi - dibandingkan dengan yang ke arah lebih rendah - daripada aturan UU ASN yang sudah diberlakukan. Hal ini mengindikasikan bahwa ada keinginan mereka untuk memperpanjang BUP lebih lama daripada 58 tahun. Hal ini berarti pula potensi untuk intensifikasi SDM PNS di lokasi penelitian masih sangat terbuka. Keinginan meninggalkan struktur birokrasi secara lebih awal (pensiun) di kalangan PNS "lebih lemah" dibanding dengan keinginan mereka untuk terus bekerja (lebih lama) dalam struktur birokrasi. Tinggal sekarang bagaimana manajemen ASN menangkap fenomena ini dan meresponnya dengan program-program pendayagunaan aparatur negara yang lebih intensif. 


\section{Jawaban Responden atas Pertanyaan : Menurut pendapat Bapak/Ibu, sebaiknya berapa tahun BUP untuk seorang PNS itu?}

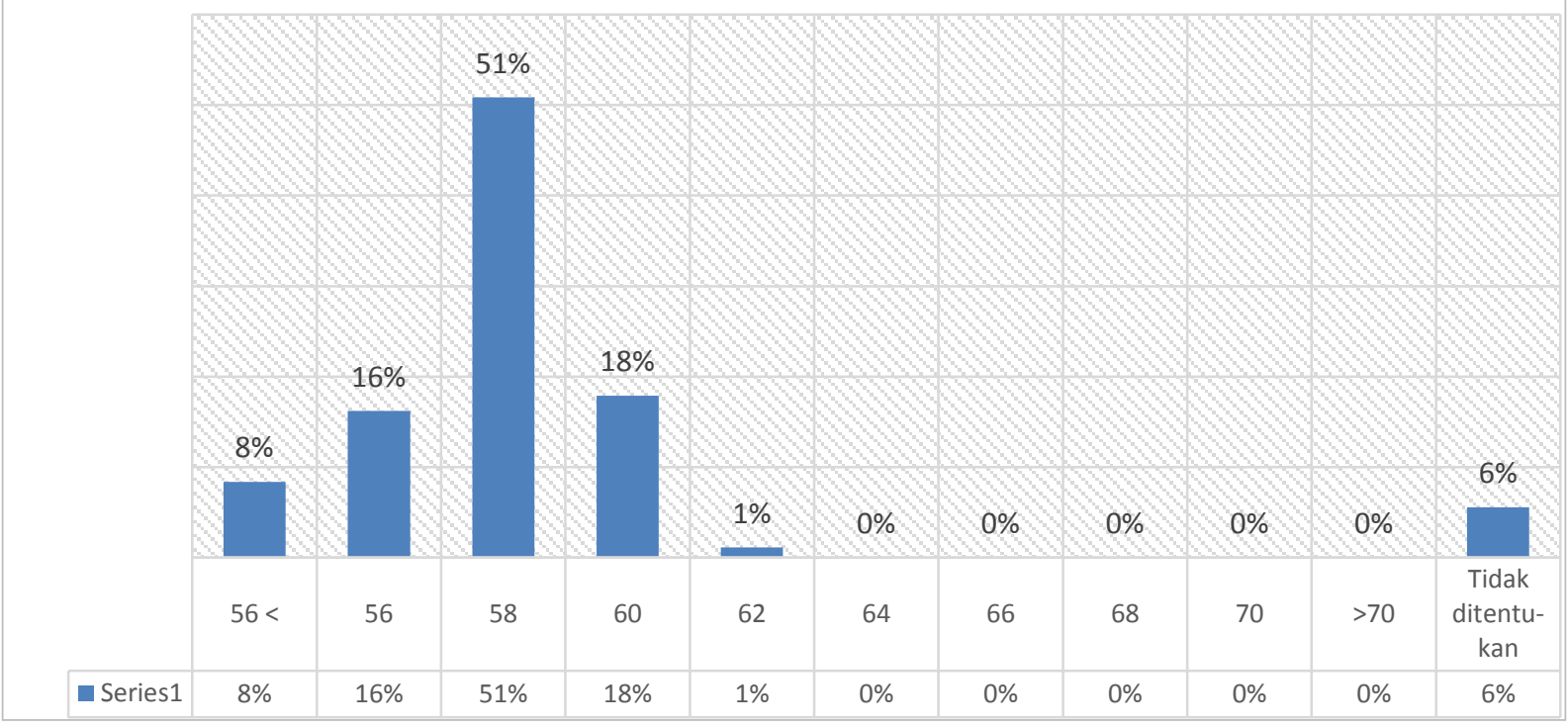

Gambar 1

Preferensi PNS tentang Batas Usia Pensiun

\section{Alasan Kesetujuan atas Kebijakan Perpanjangan BUP}

Sebagaimana dibahas dalam Kajian Pustaka ada banyak motivasi yang melatarbelakangi sikap seseorang menerima kebijakan semacam perpanjangan BUP ini, diantaranya adalah : pandangan subyektif bahwa diri mereka masih mampu bekerja, mereka masih ingin bekerja, mereka ingin memberikan kontribusi pada negara, mereka ingin diperlakukan lebih adil dibandingkan dengan PNS lain dengan BUP lebih lama, dan sebagainya. Kajian teoritis tersebut kurang-lebih sejalan dengan preferensi responden ketika diajukan pertanyaan terkait dengan alasan kesetujuan mereka terhadap kebijakan perpanjangan BUP dalam UU No. 5 Tahun 2014 - lihat Gambar 2.

Data pada gambar 2 memperlihatkan berbagai alasan yang dipilih responden. Ada 3 alternatif jawaban, yaitu (a) Menguntungkan PNS, (b) Menguntungkan Negara/Pemerintah dan (c) Meningkatkan Karier PNS secara lebih baik. Sementara itu jawaban (d) lain-lain - yang bersifat terbuka - tidak ada yang mengisi (dibiarkan kosong). Rekapitulasi jawaban semua responden tentang alasan kesetujuan mereka tersebut mengisyaratkan kepentingan pribadi PNS lebih mengedepan daripada kepentingan negara/pemerintah. Walaupun ke 3 jawaban tersebut bisa saling melengkapi, artinya menguntungkan PNS tidak selalu merugikan negara, menguntungkan negara/pemerintah tidak selalu merugikan PNS, dan meningkatkan karier PNS secara lebih baik sama artinya dengan menguntungkan PNS yang bersangkutan dan sekaligus menguntungkan negara/pemerintah, namun dari data ini terlihat mana yang lebih dikedepankan responden. Rekapitulasi data tersebut lebih banyak menggambarkan prioritas kepentingan mana yang lebih dinomorsatukan oleh responden. Apakah kepentingan individu ataukah kepentingan negara/pemerintah yang lebih diprioritaskan/dinomorsatukan terkait dengan kesetujuannya pada kebijakan perpanjangan BUP itu. 


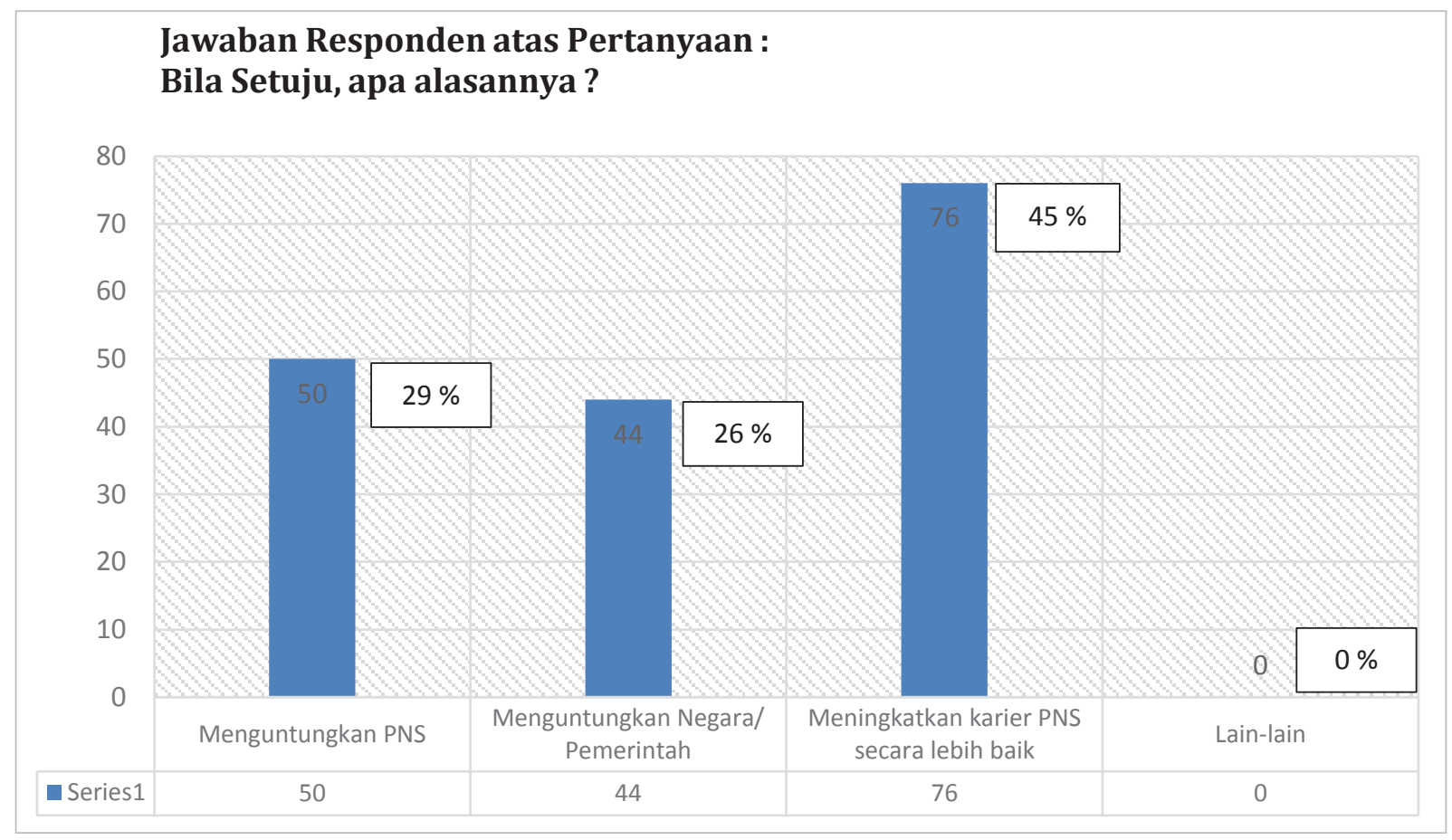

Gambar 2

Alasan Kesetujuan Responden atas Kebijakan Perpanjangan BUP

Jadi ada warning disini, terkait dengan kebijakan BUP itu, yakni pemerintah harus waspada terhadap efektivitas sasaran akhir kebijakan ini. Bisa jadi kebijakan perpanjangan BUP itu hanya dijadikan sebagai kendaraan atau instrumen individu PNS yang bersangkutan untuk meningkatkan keuntungan materialnya saja. Sementara peningkatan produktivitas untuk kepentingan publik diabaikan. Padahal peningkatan produktivitas untuk kepentingan publik itulah yang menjadi sasaran utama kebijakan ini.

Mengenai sikap PNS yang lebih mengedepankan kepentingan individu daripada kepentingan publik ini terungkap pula dalam interpretasi atas saran yang mereka ajukan Gambar 3. Walaupun persentasenya kecil (9\%), terdapat aspirasi yang menyarankan bahwa sebaiknya BUP disesuaikan dengan permintaan PNS yang bersangkutan. Lebih lanjut, untuk ranah yang lebih luas (ranah kebutuhan instansi), ada pula gagasan yang merekomendasi bahwa sebaiknya BUP itu ditentukan pemerintah secara longgar, bisa diperpanjang sesuai dengan kebutuhan instansi $(23 \%)$. 


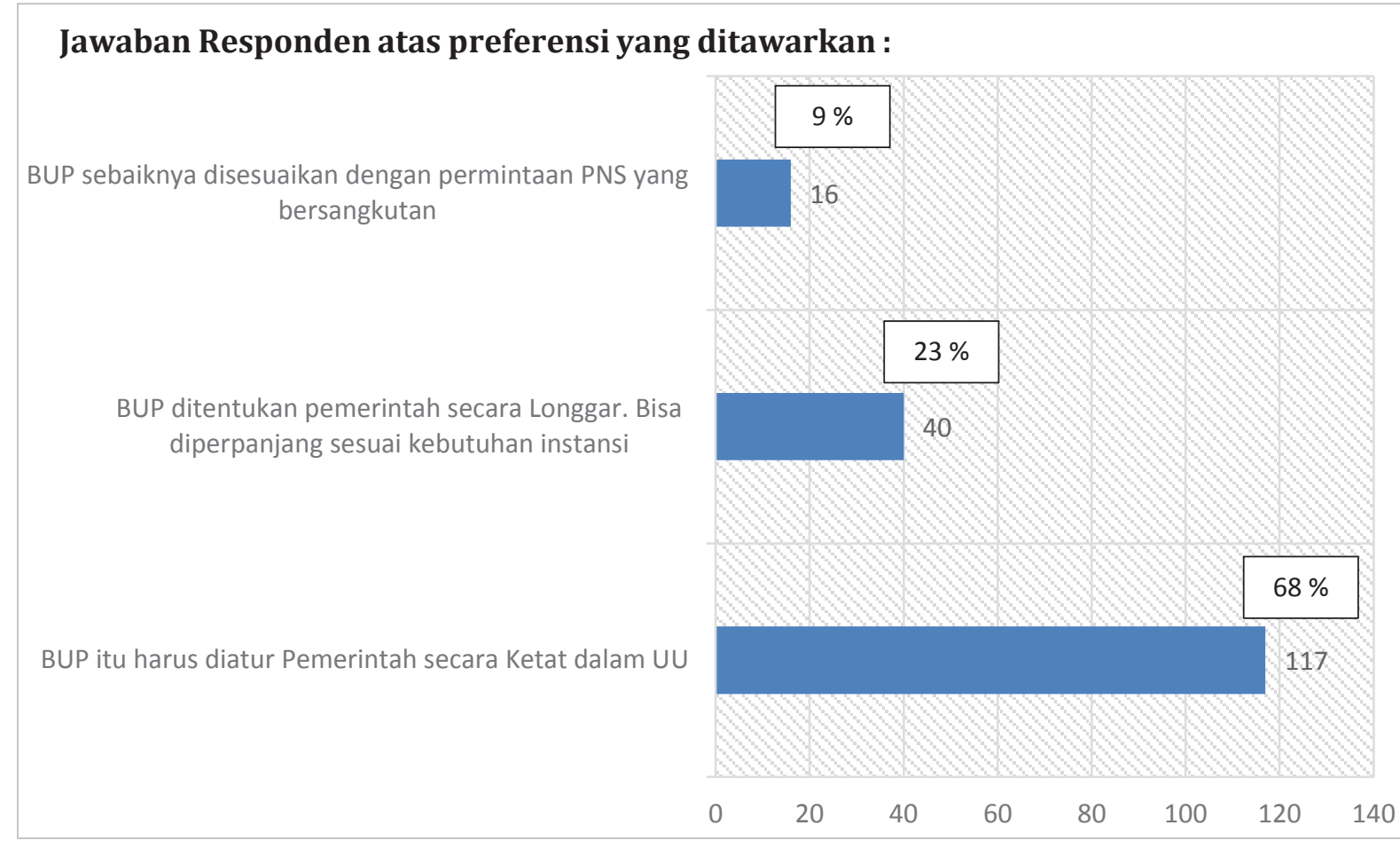

Gambar 3

Saran Responden terhadap Peraturan BUP

3. Akseptabilitas Berkorelasi dengan Tingkat Kepatuhan PNS pada Aturan Hukum

Ketika diajukan pertanyaan yang bernuasa kesetujuan responden terhadap peraturan perpanjangan BUP dari 56 ke 58 tahun untuk Pejabat Administrasi, kebanyakan di antara mereka yang dikategorikan setuju ada $72 \%$ - terdiri dari jawaban sangat setuju $(17 \%)$ dan setuju saja (55\%). Sementara itu responden yang menjawab tidak setuju hanya $27 \%$ saja. Tidak ada responden yang tidak menjawab pertanyaan ini - lihat Gambar 4. Komposisi jawaban responden yang seperti itu secara logis menunjukkan korelasi erat antara variabel akseptabilitas dengan preferensi PNS tentang BUP yang berada pada range 56 - 60 tahun sebagaimana temuan 1 penelitian ini. Fenomena ini menegaskan kembali bahwa sistem nilai birokrasi yang hierarkhis dan kepatuhan PNS pada aturan hukum di lokasi penelitian sangat tinggi. Hal ini sejalan dengan sistem nilai yang dianut dan dilestarikan dalam kehidupan birokrasi pada umumnya. Setiap insan birokrasi "ditakdirkan" harus patuh dan taat pada aturan hukum yang berlaku dan melaksanakannya, bukan mencari kelemahan aturan hukum itu sendiri - apalagi menolak atau tidak menyetujuinya. Jadi secara normatif (legalistic-formalistik) maupun empiris substansial kebijakan perpanjangan BUP tersebut telah diterima oleh kelompok sasarannya. Fenomena ini menjadi pertanda besarnya dukungan aparat birokrasi tersebut pada tahap implementasinya nanti. 


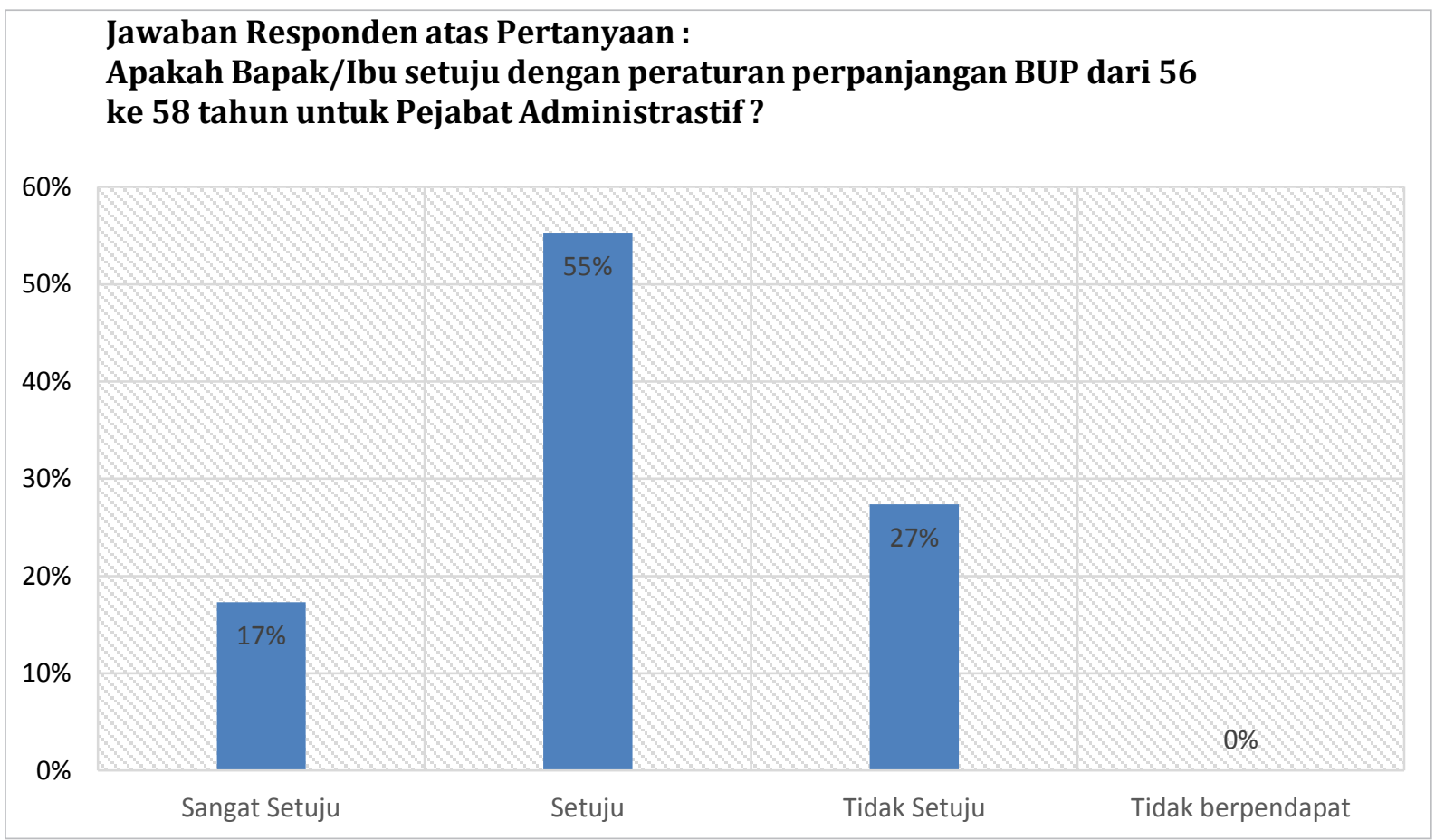

Gambar 4

Kesetujuan Responden terhadap Peraturan Perpanjangan BUP dari 56 ke 58 Tahun untuk Pejabat Administrasi

\section{SIMPULAN DAN SARAN}

1. Ada 3 pola masalah yang ditemukan dalam sistem peraturan BUP PNS sebelum lahirnya UU No. 5 Tahun 2014 itu, yaitu (a) norma regulasi BUP tidak terkoordinasi dengan baik, (b) tidak terintegrasi dan sebagian overlap dengan UU lain dalam mengatur BUP sebagai obyek yang sama, dan (c) regulasi BUP kebanyakan bersifat ad hoc yang dipermanenkan - hasil perpanjangan aturan utama. Sementara itu UU No. 5 Tahun 2014 tidak ditujukan untuk mengatasi persoalan tersebut. Oleh karena itu substansi permasalahan tersebut masih ada sampai saat ini.

2. Terkait dengan konten regulasi BUP dalam UU No. 5 tahun 2014 disimpulkan bahwa rumusan yang digunakan sebagian terlampau definitif, operasional dan terlampau teknis. Format pengaturan di tingkat UU yang seperti itu kurang tepat, karena menutup peluang diskresi untuk penyelesaian persoalan unik dan persoalan-persoalan lain yang unpredictable pada saat UU itu disusun. Format ini berpotensi memunculkan masalah implementasi di lapangan dan mendorong munculnya pelanggaran terhadap substansi aturan itu sendiri.

3. Substansi rasional hubungan kausal yang digunakan dalam peraturan BUP itu sebagian besar tidak terkait langsung dengan efektivitas pelaksanaan tugas PNS yang professional. Variabel kemampuan professional PNS dan efektivitas pelaksanaan tugas PNS itu tidak selalu dipengaruhi langsung oleh faktor usia, namun banyak faktor lain yang lebih menentukan, seperti faktor kesehatan, motivasi dan semangat kerja. Oleh karena itu penegakan peraturan BUP sebagai standar tunggal secara konsisten tidak akan berdampak pada peningkatan efektivitas dan efisiensi pelaksanaan tugas-tugas PNS yang ada, namun hanya sekedar ritual melaksanakan aturan formal yang bersifat prosedural saja. 
Oleh karena itu peningkatan kinerja organisasi pemerintahan tidak bisa diharapkan dari pelaksanaan ketentuan BUP dalam UU ASN ini. Pelaksanaan ketentuan BUP ini sebagai standar tunggal justru bisa contra-productive dalam meningkatkan profesionalisme PNS di Indonesia. Pertanyaan apa urgensi ditetapkannya BUP secara definitif dalam UU itu tidak terjawab dalam penelitian ini. Persoalan yang disasar oleh perubahan BUP dalam UU itu juga tidak jelas.

4. PNS di lokasi penelitian memiliki tingkat akseptabilitas kebijakan perubahan BUP yang tinggi. Namum memiliki karakteristik yang khas, yaitu karena sejalan dengan kepentingan pribadi PNS yang bersangkautan. Sementara itu kepentingan negara/pemerintah di nomorduakan.

5. Ada keinginan responden untuk memperpanjang BUP lebih lama daripada 58 tahun. Hal ini berarti pula potensi untuk intensifikasi SDM PNS di lokasi penelitian masih sangat terbuka. Keinginan meninggalkan struktur birokrasi secara lebih awal (pensiun) di kalangan PNS "lebih lemah" dibanding dengan keinginan mereka untuk terus bekerja (lebih lama) dalam struktur birokrasi. Fenomena ini bisa dibaca sebagai momentum yang baik bagi manajemen ASN sekarang untuk meresponnya dengan program-program pendayagunaan aparatur negara yang lebih intensif.

6. Sebaliknya, ada warning disini, terkait dengan kebijakan perpanjangan BUP itu. Negara/ pemerintah harus waspada terhadap bentuk efektivitas sasaran akhir kebijakan ini. Bisa jadi kebijakan perpanjangan BUP itu hanya dijadikan sebagai instrumen individu PNS tertentu untuk meningkatkan keuntungan - terutama keuntungan ekonomi - nya saja. Sementara peningkatan produktivitas untuk kepentingan negara terabaikan. Padahal peningkatan produktivitas untuk kepentingan negara itulah yang menjadi sasaran utama kebijakan ini.

Demikianlah hasil penelitian ini. Hasil penelitian ini akan digunakan sebagai bahan masukan penyusunaan strategi implementasi peraturan BUP dalam UU ASN ini untuk jangka panjang.

\section{REFERENSI}

Anderson, James E. 1979. Public Policy-Making. Second Edition. Holt. Rinehart and Winstone.

A. Tashakkori \& C. Teddie's (Ed). 2008. Handbook of mixed methods in social and behavioral research. 209-240. Thousand Oaks. CA: Sage.

B. Guy Peters. 2004. Governance and Publik Bureaucracy: New Forms of Democracy or New Forms of Control. The Asia Pacific Journal of Public Administration. Vol. 26, No.1 June.

Denhardt, Robert B. 1984. Theories of Public Organization. California: Brook/Cole Publishing Company.

Dunn, William, N. 1981. Public Policy Analysis: An Introduction. New Jersey: Prentice-Hall, Inc., Englewood Cliff.

Dwiyanto, Agus. 2006. Reformasi Birokrasi Publik di Indonesia. Yogyakarta: Gadjah Mada University Press. 
Dwiyanto, Agus dkk. 2006. Mewujudkan Good Governance Melalui Pelayanan Publik. Yogyakarta: Gadjah Mada University Press.

Dye, Thomas R. 2012. Understanding Public Policy. 14th edition. Publisher: Pearson.

Encarna, Valero and Gabriela Topa. 2014. Journal of Career Assessment, Vol. 23 (4): 677-685.

Grindle, Merilee S. (ed). 1980. Politics and Policy Implementation in the Third World. New Jersey: Princeton University Press.

John, Charles O. 1984. An Introduction to the Study of Public Policy. 3rd edition. Publisher: Brooks/Cole Pub Co.

Kansil, C.S.T. 2005. Sistem Pemerintahan Indonesia (Edisi Revisi). Jakarta: Bumi Aksara.

Kerlinger, Fred N. 1990. Asas-Asas Penelitian Behavioral. Yogyakarta: Gadjah Mada University Press. Terjemahan dari Foundation of Behavioral Research Third Edition 1986, by Holt Rinehart and Winston.

Lane, Frederick S. (ed). 1986. Current Issues in Public Administration. New York: St Martin's Press, Inc.

Mazmanian, Daniel A. and Paul A. Sabatier. 1983. Implementation and Public Policy. United States of America: Scott, Foresman and Company.

Peters, Guy B. 1986. American Public Policy. New Jersey: Chatham House Publisherw, Inc.

Ripley., Randall B. 1985. Policy Analysis in Political Science. Chicago: Nelson-Hall Publishers.

Sugiyono. 2008. Metode Penelitian Kuantitatif Kualitatif dan $R \& D$. Bandung: Penerbit Alfabeta.

Surbakti, Ramlan. 1992. Memahami Ilmu Politik. Jakarta: PT Gramedia Widyasarana Indonesia.

Thoha, Miftah. 2007. Perilaku Organisasi: Konsep Dasar dan Aplikasinya. Rajawali Pers.

Wahab, Abdul Solichin. 1991. Analisis Kebijaksanaan, dari Formulasi ke Implementasi Kebijaksanaan Negara. Jakarta: Bumi Aksara.

Yin, Robert K. 1989. Case Study Research, Design and Methods. Newbury Park, California: Sage Publication, Inc. 
